\title{
Serum $\beta$-heg levels between 12 to 20 weeks of gestation in prediction of hypertensive disordrers of pregnancy
}

\author{
Muthulakshmi D. ${ }^{1 *}$, Sasirekha R. ${ }^{1}$, Medha R. ${ }^{2}$ \\ ${ }^{1}$ Department of Obstetrics and Gynecology, ${ }^{2}$ Department of Biochemistry, JIPMER, Puducherry, India
}

Received: 12 July 2017

Accepted: 15 July 2017

\section{*Correspondence:}

Dr. Muthulakshmi D.,

E-mail: lakshminirms89@gmail.com

Copyright: $\odot$ the author(s), publisher and licensee Medip Academy. This is an open-access article distributed under the terms of the Creative Commons Attribution Non-Commercial License, which permits unrestricted non-commercial use, distribution, and reproduction in any medium, provided the original work is properly cited.

\begin{abstract}
Background: This study was undertaken to study the association of serum $\beta$ hCG levels between 12 to 20 weeks of gestation and development of hypertensive disorders of pregnancy and to assess the association between the levels of $\beta$ hCG and severity of hypertensive disorders of pregnancy. Study design: Prospective cohort study (200 uncomplicated primigravida).

Methods: All women between 12 to 20 weeks of pregnancy meeting the selection criteria, attended antenatal OPD in JIPMER were recruited for this study after informed consent. The venous blood samples were obtained from the subjects for $\beta$-hCG analysis. Serum $\beta$ hCG level was measured by Enzyme Linked Immunoassay System (ELISA) and expressed as $\mathrm{mIU} / \mathrm{ml}$. Multiples of median were calculated from the median of the sample population and were considered as raised if it was $>2$ MOM. The cases were followed up until delivery and observed for development of hypertensive disorders of pregnancy.

Results: Out of 200 cases, 185 cases were followed completely till term. Among 185 cases who were followed up, 10 women developed hypertensive disorders of pregnancy, accounting for $5.4 \%$ in the study group. Out of the total 185 women who were studied, 132 had $\beta$ hCG levels $\leq 2$ MOM and 53 had $\beta$ hCG levels $>2$ MOM. Among 132 women (94.7\%) with $\beta$ hCG levels $\leq 2$ MOM, 7 (5.3\%) developed hypertensive disorders. Among 53 cases (94.3\%) with $\beta$ hCG levels > 2 MOM, 3 women (5.7\%) developed hypertensive disorders. The incidence of HDP was almost similar in both the groups, 5.3\% among those whose $\beta$ hCG levels were $\leq 2 \mathrm{MOM}$ and 5.7\% among those who had $\beta$ hCG levels >2 MOM (p value - 0.923).

Conclusions: From the present study, it may be concluded that high serum $\beta$ hCG levels ( 2 MOM) estimated between 12 to 20 weeks of pregnancy were not predictive of development of hypertensive disorders later in pregnancy.
\end{abstract}

Keywords: $\beta$ hCG, Hypertensive disorders, Preeclampsia

\section{INTRODUCTION}

Hypertensive disorders of pregnancy (HDP) are unique to pregnancy, affecting $5 \%$ to $8 \%$ of all pregnant women. ${ }^{1}$ In spite of the improvement in maternal and neonatal care, hypertensive disorders of pregnancy are major causes of maternal and perinatal morbidity and mortality in both developed and developing countries. Numerous clinical and biochemical markers have been proposed to predict preeclampsia. $^{2}$

As preeclampsia is characterized by disturbed trophoblastic pathology, early placental dysfunction could be reflected by altered hCG concentrations. Therefore, this study is being done to find out the levels of serum $\beta$ hCG in pregnant women between 12 to 20 
weeks of gestation and its association with the risk of developing hypertensive disorders of pregnancy.

\section{METHODS}

This study was done to find out the $\beta$ hCG levels between 12 to 20 weeks and its association with development of hypertensive disorders of pregnancy at later gestational age. The present cohort study was conducted in the Departments of Obstetrics and Gynaecology and Biochemistry, JIPMER, Puducherry, India from September 2013 to July 2015 after approval from the JIPMER research committee and Institute Ethics Subcommittee. All uncomplicated primigravida attending antenatal clinic at JIPMER with gestational age between 12 to 20 weeks were recruited in this study. The exclusion criteria were multiple pregnancy, congenital malformation of fetus, chromosomal anomalies, secondary hypertension, Antiphospholipid antibody syndrome, diabetes mellitus and molar pregnancy.

Detailed obstetric history and examination were done. Baseline characteristics like age, height, weight, BMI, blood pressure was documented. Along with routine haematological investigations, $\beta$ hCG was measured by Enzyme Linked Immunoassay System (ELISA) and expressed as $\mathrm{mIU} / \mathrm{ml}$. Multiples of median were calculated from the median of the sample population and were considered as raised if it was >2 MOM. Mean blood pressure at each visit was noted. The cases were followed up until delivery and observed for development of hypertensive disorders of pregnancy. The patients who developed hypertensive disorders of pregnancy were labelled according to the NHBPEP classification and blood investigations like complete haemogram along with peripheral smear, renal function test, liver function test and coagulation profile. The gestational age at delivery was noted. The outcome of pregnancy and antepartum, intrapartum, postpartum complications of hypertensive disorders were noted.

\section{Statistical analysis}

The normality of the level of $\beta$ hCG was tested using Kolmogorov-Smirnov test. The distribution of the pregnancy outcome was presented as frequencies and percentages and was compared between the groups using Pearson's chi-square test. The levels of serum $\beta$ hCG and the outcome of pregnancy was compared by MannWhitney U test. All statistical analysis was carried out at $5 \%$ level of significance $(\mathrm{p}<0.05)$.

\section{RESULTS}

Out of 200 cases, 185 cases were followed completely till term. The outcome of pregnancy after enrolment was shown in Table 1. Among 185 cases who were followed up, 10 women developed hypertensive disorders of pregnancy, accounting for $5.4 \%$ in the study group. This was similar to the general incidence of preeclampsia $(5 \%$ to $8 \%$ ).

Table 1: Outcome of pregnancy after recruitment.

\begin{tabular}{|ll|}
\hline Total No. of women recruited & 200 \\
\hline Spontaneous abortion & $5(2.5 \%)$ \\
\hline Missed abortion & $2(1 \%)$ \\
\hline Lost to follow up & $8(4 \%)$ \\
\hline No. of cases followed till term & $185(92.5 \%)$ \\
\hline
\end{tabular}

Among 185 cases, 175 women were found to be normotensive and 10 women developed hypertensive disorders of pregnancy (Figure 1). The distribution of serum $\beta$ hCG level among two groups was shown in Table 2.

Table 2: Serum $\beta$ hCG levels and distribution of cases.

\begin{tabular}{|lllll|}
\hline$\beta-h C G$ & $\begin{array}{l}\text { No. of } \\
\text { cases }\end{array}$ & $\%$ & Normotensive & HDP \\
\hline$\leq 30,000$ & 42 & 21.0 & 39 & 3 \\
\hline $\begin{array}{l}30,001- \\
40,000\end{array}$ & 32 & 16.0 & 31 & 1 \\
\hline $\begin{array}{l}40,001- \\
50,000\end{array}$ & 23 & 11.5 & 22 & 1 \\
\hline $\begin{array}{l}50,001- \\
60,000\end{array}$ & 9 & 4.5 & 8 & 1 \\
\hline $\begin{array}{l}60,001- \\
70,000\end{array}$ & 9 & 4.5 & 9 & 0 \\
\hline $\begin{array}{l}70,001- \\
80,000\end{array}$ & 10 & 5.0 & 10 & 0 \\
\hline $\begin{array}{l}80,001- \\
90,000\end{array}$ & 7 & 3.5 & 6 & 1 \\
\hline $\begin{array}{l}90,001- \\
1,00,000\end{array}$ & 7 & 3.5 & 7 & 0 \\
\hline $\begin{array}{l}1,00,001- \\
1,50,000\end{array}$ & 18 & 9.0 & 17 & 1 \\
\hline $\begin{array}{l}1,50,001- \\
2,00,000\end{array}$ & 14 & 7.0 & 13 & 10 \\
\hline $\begin{array}{l}2,00,001- \\
2,50,000\end{array}$ & 10 & 5.0 & 10 & 0 \\
\hline $\begin{array}{l}2,50,001- \\
3,00,000\end{array}$ & 7 & 3.5 & 7 & 0 \\
\hline $\begin{array}{l}3,00,001- \\
3,50,000\end{array}$ & 4 & 2.0 & 4 & 1 \\
\hline$>3,50,000$ & 8 & 4.0 & 7 & 190 \\
\hline Total & 200 & 100.0 & 19 \\
\hline$D P-H y p$ & & & \\
\hline
\end{tabular}

HDP - Hypertensive disorders of pregnancy.

Demographic variables (Table 3) like age, haemoglobin, height, weight, BMI, systolic and diastolic blood pressure at first visit were comparable in both the groups and they were not statistically significant. Most of the women were between 23-25 years. There were totally nine teenage $(<20$ years $)$ pregnancies, eight in the normotensive group and one in the hypertensive group. In our study, majority were <35 years except one woman who was 35 years and remained normotensive throughout 
the pregnancy. There were totally four women who had BMI $>25 \mathrm{~kg} / \mathrm{m}^{2}$, three in the normotensive group and one in the hypertensive group. The mean gestational age at which the samples were collected in the normotensive group was 116 days compared to 121 days in the hypertensive group and it was not statistically significant $(\mathrm{p}$-value $=0.456)$. Most of the samples were taken after 15 weeks of gestation (124 cases in the normotensive group, seven cases in the hypertensive group). However, these differences were comparable between both the groups.

Table 3: Demographic variables among the study group.

\begin{tabular}{|c|c|c|}
\hline Variable & $\begin{array}{l}\text { Normotensive } \\
(\text { mean } \pm \text { SD })\end{array}$ & $\begin{array}{l}\text { Hypertensive } \\
(\text { mean } \pm \text { SD })\end{array}$ \\
\hline Age (years) & $23.56 \pm 3.51$ & $24.60 \pm 3.68$ \\
\hline Haemoglobin $(\mathrm{gm} \%)$ & $10.01 \pm 1.11$ & $10.90 \pm 1.11$ \\
\hline Height $(\mathrm{cm})$ & $154.30 \pm 4.94$ & $155.90 \pm 6.06$ \\
\hline Weight(kg) & $51.19 \pm 7.85$ & $55.60 \pm 7.35$ \\
\hline $\begin{array}{l}\text { Body mass index } \\
\left(\mathrm{kg} / \mathrm{m}^{2}\right)\end{array}$ & $21.43 \pm 3.11$ & $22.81 \pm 2.28$ \\
\hline $\begin{array}{l}\text { Systolic blood } \\
\text { pressure at first } \\
\text { visit }(\mathrm{mm} \text { of } \mathrm{Hg} \text { ) }\end{array}$ & $110.26 \pm 10.36$ & $117.00 \pm 10.59$ \\
\hline $\begin{array}{l}\text { Diastolic Blood } \\
\text { pressure at first } \\
\text { visit ( } \mathrm{mm} \text { of } \mathrm{Hg} \text { ) }\end{array}$ & $72.88 \pm 8.56$ & $76 \pm 6.99$ \\
\hline $\begin{array}{l}\text { GA at } \beta \text {-hCG } \\
\text { sampling (days) }\end{array}$ & $116.83 \pm 17.38$ & $121.10 \pm 21.20$ \\
\hline
\end{tabular}

Table 4: Distribution of cases according to hypertensive status and $\beta$-hCG levels.

\begin{tabular}{|c|c|c|}
\hline \multirow{3}{*}{$\begin{array}{l}\text { B -hCG levels (MOM) } \\
(53,644)\end{array}$} & \multicolumn{2}{|c|}{$\begin{array}{l}\text { Hypertensive disorders } \\
\text { of pregnancy }\end{array}$} \\
\hline & No & Yes \\
\hline & $\begin{array}{l}\text { No. of cases } \\
(\%)\end{array}$ & $\begin{array}{l}\text { No. of } \\
\text { cases }(\%)\end{array}$ \\
\hline$\leq 2$ & $125(94.7)$ & $7(5.3)$ \\
\hline$>2$ & $50(94.3)$ & $3(5.7)$ \\
\hline Total & 175 & 10 \\
\hline
\end{tabular}

The relationship between $\beta$ hCG levels (MOM) and hypertensive disorders was shown in Table 4. Out of the total 185 women who were studied, 132 had $\beta$ hCG levels $\leq 2 \mathrm{MOM}$ and 53 had $\beta$ hCG levels $>2$ MOM. Among 132 women $(94.7 \%)$ with $\beta$ hCG levels $\leq 2$ MOM, seven women $(5.3 \%)$ developed hypertensive disorders.

Among 53 cases (94.3\%) with $\beta$ hCG levels > 2 MOM, three women $(5.7 \%)$ developed hypertensive disorders. The incidence of HDP was almost similar in both groups, $5.3 \%$ among those whose $\beta$ hCG levels were $\leq 2 \mathrm{MOM}$ and $5.7 \%$ among those who had $\beta$ hCG levels $>2$ MOM (p value -0.923 ).
The serum $\beta$ hCG levels did not follow normal distribution. Hence the median $\beta$ hCG value was taken for both groups and it was not statistically significant (Table 5).

Table 5: Serum $\beta$ hCG levels between two groups.

\begin{tabular}{llll} 
Group & $\begin{array}{l}\text { Normotensive- } \\
\text { group } \\
\text { Median (IQR) }\end{array}$ & $\begin{array}{l}\text { Hypertensive } \\
\text { group } \\
\text { Median (IQR) }\end{array}$ & $\begin{array}{l}\text { p- } \\
\text { value }\end{array}$ \\
$\begin{array}{l}\text { Serum } \beta \\
\text { hCG }\end{array}$ & $\begin{array}{l}52,654 \\
(33,176-\end{array}$ & $\begin{array}{l}47,779 \\
(25,985-\end{array}$ & \\
level & $1,29,577)$ & $1,47,706)$ & 0.841 \\
$(\mathrm{mIU} / \mathrm{ml})$ & & & \\
\hline
\end{tabular}

IQR-Interquartile range.

The relationship between serum $\beta$ hCG levels and severity of hypertensive disorders was shown in Table 6.

Table 6: Mean serum $\beta$ hCG levels in hypertensive disorders.

\begin{tabular}{|lll|l|}
\hline HDP & $\begin{array}{r}\text { No. of } \\
\text { cases }\end{array}$ & $\begin{array}{l}\text { Mean serum } \beta \\
\text { hCG level } \\
(\mathrm{m} / \mathrm{U} / \mathrm{ml})\end{array}$ & $\begin{array}{l}\text { No. of cases } \\
\text { received } \\
\text { magnesium } \\
\text { sulphate }\end{array}$ \\
\hline GHTN & 2 & $19,444.5$ & 0 \\
\hline MPE & 2 & 32016.5 & 0 \\
\hline SPE & 6 & $1,64,003$ & 6 \\
\hline
\end{tabular}

HDP-Hypertensive disorders of pregnancy; GHTN-Gestational hypertension; MPE-Mild preeclampsia; SPE-Severe preeclampsia.

Among 10 women who developed hypertensive disorders of pregnancy, the mean serum $\beta$ hCG level among those who developed severe preeclampsia was 1, 64,003 $\mathrm{mIU} / \mathrm{ml}$ which was much higher than those who developed mild preeclampsia (32016.5 $\mathrm{mIU} / \mathrm{ml})$ and gestational hypertension $(19,444.5 \mathrm{mIU} / \mathrm{ml})$.

\section{DISCUSSION}

Adverse pregnancy outcomes like preeclampsia, placental dysfunction, chromosomal abnormalities and intra uterine growth restriction have been explained with elevated second trimester hCG levels. For most of these outcomes, the cut off value of $\beta$ hCG was found to be 2-2.5 MOM. During early pregnancy, hCG was responsible for spiral artery remodelling. Various studies have shown that placental hypoxia might be responsible for increased hCG production.

It was proved by in vitro trophoblastic cell culture that was grown under hypoxic conditions. Placental abnormalities like villitis, infarction, ischemic changes and intervillus thrombosis were also associated with increased serum $\beta$ hCG levels. ${ }^{3}$ The impaired spiral artery vasculature and subsequent reduced blood flow in the placental villi were responsible for intrauterine growth restriction. 


\section{Demographic variables}

The baseline characteristics like age, height, weight, BMI, haemoglobin levels between were comparable and did not have the significant difference. Within the groups the mean age was comparable being $23.56 \pm 3.51$ years in the normotensive group and $24.60 \pm 3.68$ years among hypertensive group. The mean BMI was also comparable between the groups with $21.43 \pm 3.11 \mathrm{~kg} / \mathrm{m}^{2}$ in the normotensive group and $22.81 \pm 2.28 \mathrm{~kg} / \mathrm{m}^{2}$ among those who developed the hypertensive group. The mean haemoglobin values were similar in both the groups with $10.01 \pm 1.11 \mathrm{gm} / \mathrm{dl}$ and $10.90 \pm 1.11 \mathrm{gm} / \mathrm{dl}$ in normotensive and hypertensive group respectively.

\section{Serum $\beta$ hCG levels and pregnancy outcome}

According to serum $\beta$ hCG levels, the study group was divided into two groups ( $>2 \mathrm{MOM}, \leq 2 \mathrm{MOM})$. It was based on the study conducted by Kaur et al which had the sensitivity of $90.91 \%$, the specificity of $97.44 \%$ and the positive predictive value of $83.33 \%$ for this cut off value. ${ }^{4}$ In their study, 22 cases developed hypertensive disorders among 178 cases. Among 22 cases, 20 cases had $\beta$ hCG levels > 2 MOM. They also proved that severity of hypertensive orders was directly proportional to the level of $\beta$ hCG. ${ }^{3}$ The study conducted by Roizhernandez et al also showed that the sensitivity, specificity and positive predictive value were high, if the cut- off serum $\beta$ hCG was $2 \mathrm{MOM}^{3}$ (Table 7).

Table 7: Predictive accuracy of $\beta$ hCG in hypertensive disorders of pregnancy.

\begin{tabular}{|llll|}
\hline Study & Sensitivity & Specificity & $\begin{array}{l}\text { Positive } \\
\text { predictive } \\
\text { value }\end{array}$ \\
\hline Kaur et al & $90.91 \%$ & $97.44 \%$ & $83.33 \%$ \\
$\begin{array}{l}\text { Roiz- } \\
\text { hernandez et } \\
\text { al }\end{array}$ & $\begin{array}{l}88.5 \% \\
\text { (Primi) }\end{array}$ & $\begin{array}{l}92 \% \\
\text { (Primi) }\end{array}$ & $\begin{array}{l}46 \% \\
\text { (Primi) }\end{array}$ \\
\cline { 2 - 4 } & $\begin{array}{l}100 \% \\
\text { (Multi) }\end{array}$ & $\begin{array}{l}85.6 \% \\
\text { (Multi) }\end{array}$ & $\begin{array}{l}25 \% \\
\text { (Multi) }\end{array}$ \\
\hline
\end{tabular}

In the present study, out of 185 cases, 53 cases had $\beta$ hCG levels >2 MOM. Only three cases out of 53 developed HDP. Out of 132 cases with $\beta$ hCG levels $\leq 2$ MOM, seven cases had HDP. We did not find the association between $\beta$ hCG levels $\geq 2$ MOM and development of hypertensive disorders of pregnancy. The distribution of hypertensive disorders among two groups was similar and it was not statistically significant.

Although studies (Kaur et al) have proven the association between elevated $\beta$ hCG levels in the second trimester and subsequent development of hypertensive disorders, our study did not find the association as similar to study conducted by Stamilo et al and Mikic et al (retrospective studies) and Raty et al and Morssink et al (prospective studies).
Table 8: Serum $\beta$ hCG levels in normotensive and hypertensive group.

\begin{tabular}{|c|c|c|}
\hline Study & Hypertensive group & $\begin{array}{l}\text { Normotensive } \\
\text { group }\end{array}$ \\
\hline \multirow{3}{*}{$\begin{array}{l}\text { Ratty et } \\
\text { al }\end{array}$} & 1.01 MOM in SPE & \multirow{3}{*}{$0.91 \mathrm{MOM}$} \\
\hline & 1.07 MOM in MPE & \\
\hline & $0.99 \mathrm{MOM}$ in GHTN & \\
\hline $\begin{array}{l}\text { Morssink } \\
\text { et al }\end{array}$ & $\begin{array}{l}0.048 \pm 0.265 \\
(\text { mean logaritham) }\end{array}$ & $\begin{array}{l}0.010 \pm 0.244 \\
\text { (mean } \\
\text { logaritham) }\end{array}$ \\
\hline $\begin{array}{l}\text { Present } \\
\text { study }\end{array}$ & $0.89 \mathrm{MOM}$ & $1.01 \mathrm{MOM}$ \\
\hline
\end{tabular}

GHTN-Gestational hypertension; MPE-Mild preeclampsia; SPE-Severe preeclampsia; MOM - Multiples of median.

Stamilo et al found that out of 1998 patients, only 49 patients developed severe preeclampsia. The serum $\beta$ hCG levels and serum alpha fetoprotein levels were similar in both cases and controls. It was a retrospective study and they proposed that nulliparity, history of preeclampsia and elevated mean arterial pressure were significantly associated with severe preeclampsia rather than serum $\beta$ hCG. Both the case and control groups had similar $\beta$ hCG levels. ${ }^{5}$

Mikic et al conducted a study between 1992 to 1997 in which study population was divided into two groups based on $\beta$ hCG levels ( $\geq 3.5$ MOM, 192 cases; $\leq 2$ MOM, 218 cases). There was no significant difference in the distribution of hypertensive disorders among two groups ( 2 cases in $\geq 3.5$ MOM, 5 cases in $\leq 2$ MOM). They found that mid -trimester $\beta$-hCG was not predictive of maternal outcomes like intrauterine growth restriction and hypertensive disorders. Stamilo et al. found that out of 1998 patients, only 49 patients developed severe preeclampsia. The serum $\beta$ hCG levels and serum alpha fetoprotein levels were similar in both cases and controls. It was a retrospective study and the medical records were examined retrospectively. They proposed that nulliparity, history of preeclampsia and elevated mean arterial pressure were significantly associated with severe preeclampsia rather than serum $\beta$ hCG. ${ }^{6}$

Another prospective study conducted by Ratty et al has shown that there was no difference in $\beta$ hCG levels in both the normotensive and hypertensive groups. Among 351 cases, 69 women had hypertensive disorders and 282 women were normotensive. In this study, there was no difference in the $\beta$ hCG levels between the groups (1.01 MOM in SPE, 1.07 MOM in MPE, 0.99 MOM in GHTN and $0.91 \mathrm{MOM}$ in the control group. ${ }^{7}$

Morssink et al measured serum $\beta$ hCG levels in 390 patients. Out of 390 patients, 65 had hypertensive disorders and 325 women were normotensive. The mean logarithms of the $\beta$ hCG between the two groups were not significant $(0.048 \pm 0.265$ in the hypertensive group, $0.010 \pm 0.244$ in the control group). ${ }^{8}$ 
Even though basic pathology for HDP lies in the placenta, what exactly initiates abnormal trophoblastic invasion is still not known. The development of HDP could still be predicted to a reasonable extent by combination of maternal characteristics (nulliparity, previous history of preeclampsia), biochemical and radiological markers rather than single parameter.

\section{Serum $\beta$ hCG levels and severity of preeclampsia}

In the present study, only 10 cases developed hypertensive disorders. The mean serum $\beta$ HCG level in patients who had severe preeclampsia was very high when compared to patients having mild preeclampsia and gestational hypertension. This was similar to studies conducted by Ratty et al and Lee et al. ${ }^{7,9}$ The sample size is not adequate enough to identify the statistical significance between levels of serum $\beta$ hCG and severity of hypertensive orders.

Table 9: Serum $\beta$ hCG levels in hypertensive disorders of pregnancy.

\begin{tabular}{|lll|l|}
\hline $\begin{array}{l}\text { Study } \\
\text { Ratty }\end{array}$ & $\begin{array}{l}\text { Gestational } \\
\text { hypertension }\end{array}$ & $\begin{array}{l}\text { Mild } \\
\text { preeclampsia }\end{array}$ & $\begin{array}{l}\text { Severe } \\
\text { preeclampsia }\end{array}$ \\
\hline $\begin{array}{l}\text { et al } \\
\text { 0.99 MOM }\end{array}$ & $\begin{array}{l}1.07 \mathrm{MOM} \\
1.01 \mathrm{MOM}\end{array}$ \\
\hline $\begin{array}{l}\text { Lee et al } \\
\text { - }\end{array}$ & $\begin{array}{l}1.33 \pm 1.00 \\
\mathrm{MOM}\end{array}$ & $\begin{array}{l}1.66 \pm 1.14 \\
\text { MOM }\end{array}$ \\
\hline $\begin{array}{l}\text { Present } \\
\text { study }\end{array}$ & $0.36 \mathrm{MOM}$ & $0.59 \mathrm{MOM}$ & $3.05 \mathrm{MOM}$ \\
\hline
\end{tabular}

\section{CONCLUSION}

From the present study, it may be concluded that high serum $\beta$ hCG levels (2MOM) estimated between 12 to 20 weeks of pregnancy were not predictive of development of hypertensive disorders later in pregnancy.

\section{ACKNOWLEDGMENTS}

Authors would like to thank Dr. Sasirekha R., Dr. Medha R., Prof. Soundara Raghavan S., Prof. Syed Habeebullah, Prof. Reddy Rani, Prof. Dasari Papa, Prof. Chaturvedula and Prof. Gowri, Prof. Zacchariah Bobby for support during study.

\section{Funding: JIPMER intramural research committee} Conflict of interest: None declared

Ethical approval: The study was approved by JIPMER

\section{REFERENCES}

1. Report of the National High Blood Pressure Education Program. Working group report on high blood pressure in pregnancy. Am J Obstet Gynecol. 2000;183(1):S1-S22.

2. Conde-Agudelo A, Villar J, Lindheimer M. World Health Organization Systematic Review of Screening Tests for Preeclampsia. J Obstet Gynaecol Ind. 2004;104(6):1367-91.

3. Roiz-Hernandez J, de Cabello-Martinez J, Fernandez Mejia M. Human chorionic gonadotropin levels between 16 and 21 weeks of pregnancy and prediction of preeclampsia. Int $\mathbf{J}$ Gynecol Obstet. 2006; 92:101-5.

4. Kaur G, Jain V, Mehta S, Himani S. Prediction of PIH by maternal serum B hCG levels in the second trimester of pregnancy. J Obstet Gynecol India. 2012;62(1):32-4.

5. Stamilo DM, Sehdev HM, Morgan MA, Propert K, Macones GA. Can antenatal clinical and biochemical markers predict the development of severe preeclampsia? Am J Obstet Gynecol. 2000;182(3):589-94.

6. Mikic TS, Johnson P. Second trimester maternal serum $\beta$ human chorionic gonadotrophin and pregnancy outcome. $\mathrm{Br} \mathrm{J}$ Obstet Gynecol. 1999;106(6):598- 600.

7. Raty R, Koskinen P, Alanen A, Irjala K, Matinlauri I, Ekblad U. Prediction of Pre-eclampsia with Maternal Mid-trimester Total Renin, Inhibin A, AFP and Free-hCG Levels. Prenat Diagn. 1999;19(2):1227.

8. Morssink LP, Heringa MP, Beekhuis JR, De Wolf BT, Mantingh A. The association between hypertensive disorders of pregnancy and abnormal second-trimester maternal serum levels of hCG and alpha-fetoprotein. Obstet Gynecol. 1997;89(5.1):66670.

9. Lee L, Sheu B, Shau W, Liu D, Lee y, Huang S. Mid-trimester b-hCG levels incorporated in a multifactorial model for the prediction of severe preeclampsia. J Prenat Diagn. 2000;20(9):738-43.

Cite this article as: Muthulakshmi D, Sasirekha R, Medha R. Serum $\beta$-hcg levels between 12 to 20 weeks of gestation in prediction of hypertensive disordrers of pregnancy. Int J Reprod Contracept Obstet Gynecol 2017;6:3347-51. 